\title{
Organophosphorous Pesticides: Their Effects on Biosenti- nel Species and Humans. Control and Application in Chile
}

\author{
Pesticidas Organofosforados: Sus Efectos en Especies Biosentinelas \\ y Humanos. Control y Aplicación en Chile
}

Omar Espinoza-Navarro ${ }^{1 *}$; Carlos Ponce-LaRosa ${ }^{2,3}$ \& Eduardo Bustos-Obregón ${ }^{3 \dagger}$

ESPINOZA-NAVARRO, O.; PONCE-LAROSA, C. \& BUSTOS-OBREGÓN, E. Organophosphorous pesticides: Their effects on biosentinel species and humans. Control and application in Chile. Int. J. Morphol., 35(3):1069-1074, 2017.

SUMMARY: The environment is negatively affected by the increasing accumulation of both natural and man-made waste and by-products. Organophosphorous pesticides - malathion, diazinon and methamidophos- are used worldwide in pest control. The aim of this report is to review the effects of organophosphates on the male reproductive tract of mice, rats and earthworms, and to evaluate their projection into the human population. Assessing failures in the male reproductive system is an excellent in vivo biomarker to determine the level of toxicity of suspected pollutants. In rodents organophosphates cause decreased testicular weight and sperm density, abnormal tubular plugging and increased teratozoospermia. In earthworms they cause a significant decrease in body weight and alter the spermatheca, with an initial significant increase in immature sperm followed by a significant decrease in sperm count with high frequency of metachromasia. Given the environmental impact of these pesticides -and their potential effects on human health-, international and regional organizations are warning about the correct handling and managing of these substances during work-related and domestic exposures and about their relation to water sources and food, placing a greater emphasis on the school children population due to its higher vulnerability, reduced detoxification capacity, and their endocrine and physiological effects.

KEY WORDS: Organophosphates; Cytotoxicity; Biomonitoring; Reproductive Health; Occupational Exposure.

\section{INTRODUCTION}

The environment is being increasingly altered by the presence and accumulation of waste and by-products arising from both natural origin and man-made activities. Anthropogenic pollution is expressed in a continuously increasing list of chemical substances such as drugs, food additives or pesticides, which would be largely responsible for extensive damage and morphologic and genetic alterations to several life forms (ATSDR, 2000; Bustos-Obregón \& Hartley, 2008).

Currently, more than 100,000 commonly used chemical products are identified; most of them are emerging contaminants what act as endocrine disruptors. Their deleterious effects are exerted by altering the hypothalamic-pituitary axis, or via actions that modify other organic regulatory components such as the immune and the nervous systems.
Organophosphate insecticides are the most commonly used in agriculture. This type of insecticide acts by inhibiting acetylcholinesterase, an enzyme that prevents nerve impulses -specifically those heading to muscles and those traveling via cholinergic fibers of the autonomic nervous system- acting in a persistent fashion. Inhibition of this enzyme results in the accumulation of acetylcholine, responsible for the clinical manifestations of poisoning in animals and humans (Bello-Ramírez et al., 2000; Joshi \& Sharma, 2011).

Organophosphates (OP) are esters of phosphoric acid with electrophilic properties and esterase phosphorylating capacity. Exposure to high concentrations of OPs can cause symptoms like nausea, headaches, shortness of breath, lack of coordination, paralysis and muscle spasms and even genotoxic action (Rodríguez \& Bustos-Obregón, 2000; Baconi et al., 2013).

\footnotetext{
${ }^{1}$ Department of Biology, Universidad de Tarapacá, Arica, Chile

${ }^{2}$ School of Science, Universidad San Sebastián, Santiago, Chile

${ }^{3}$ School of Medicine, ICBM, Universidad de Chile, Santiago, Chile

$\dagger$ In memoriam
} 
The toxicity of these pesticides is due to the action of its metabolites, such as malaoxon and isomalathion which are 40 times more toxic than malathion itself. In vitro studies describe that malaoxon can induce DNA breaks in places where oncogenes or tumor suppressor genes are located, so that this metabolite may be considered as a carcinogenic and a mutagenic agent. In mammals, OP degradation occurs through hydrolytic phosphatases and carboxyl esterases (Blasiak et al., 1999; Espinoza-Navarro \& Bustos-Obregón, 2005).

The aim of this study was to analyze the effects of the organophosphorus insecticides malathion, diazinon and methamidophos on the biology of the reproductive system of male rats, mice and earthworms and their projected effects on human public health, especially on occupational exposed adults and children.

Lab mice and rats (Rattus norvegicus, Mus musculus) are scientifically recognized as proper biosentinel species due to their behavior patterns, eating habits, high reproductive rate, ease of maintenance and standardized genotype. Another model for environmental monitoring is the earthworm Eisenia foetida. It is easy to handle and inexpensive to maintain. Its reproduction is continuous throughout the year, and it helps to maintain soil structure and fertility. Since worms are in direct contact with the soil, both externally and internally through the skin and gastrointestinal tract, respectively, they are able to absorb pesticides five to ten times faster than soil itself or mineral substrates. The earthworm Eiseniafoetida is thus considered one of the best models for ecotoxicity studies (Phugare et al., 2012).

\section{MATERIAL AND METHOD}

This review was prepared summarizing data obtained from the research groups leaded by Dr. Eduardo Bustos-Obregón, emeritus researcher from Universidad de Chile (1937-2014). The working methodology was based on the review and selection of articles and results from our group and the comparison and evaluation of currently available national and international literature focused on the deleterious effects of contamination due to organophosphates, both in general as well as specifically with malathion, diazinon and methamidophos. Knowing these results, a projection of the effect of these pesticides in human populations was made at a work level, as well as in students exposed to these contaminants in their environment.

Malathion is an organophosphorus chemical compound whose chemical formula is 0,0 -dimethyl-S-(1,2-di- carbetoxy-ethyl)-phosphorodithioate. It is considered of low toxicity to mammals and was widely used in public health. It is used as a systemic pesticide that acts upon contact and ingestion to combat insects in foliage and soil. Absorbed through the airways, digestive tract and skin, it can cause death from respiratory failure in humans since the elevated concentration of acetylcholine blocks neuromuscular transmission (Yasmin \& D' Souza, 2010; EPA, 2012).

Diazinon: (0,0-diethyl-0- [6-methyl-2- (1-methylethyl)- 4 pyrimidinyl] phosphorothioate) is an organophosphoric insecticide that presents a structural chemical formula similar to parathion (A very toxic organic phosphorus and currently prohibited its distribution) and can, therefore, be a possible cytotoxic and genotoxic agent for germinal cells. This synthetic insecticide is one of the most used in agriculture and pest control worldwide (Salazar-Arredondo, et al., 2008).

Methamidophos is an organophosphorous chemical compound with the common name O, S-dimethyl phosphoroamidothioate. It is used as a systemic pesticide with action by contact and ingestion used to combat chewing and sucking insects; it can be absorbed by ingestion, inhalation and contact. It is distributed under the trade name of Tamaron 600, Monitor 600, MTD 600SL and methamidophos 60. In human males, alterations in sperm chromatin integrity have been reported (García-Santos \& Keller-Forrer, 2011).

Assessment of male reproduction and pollutants. Induction of failures in the male reproductive system and the consequent alteration in spermatogenesis in animals treated with chemicals, are considered excellent in vivo models to assess the degree of toxicity of pollutants, since the shape of the sperm is characteristic of every species, as shown in Figure 1 (Espinoza-Navarro \& Bustos-Obregón, 2014).

Spermatogenesis in the testes of mammals is the sum of several processes that in adult individuals end up with the production of sperm cells, which are released from the germinal epithelium during spermiation into the epididymis where they experience other morphological and physiological changes, such as migration of the cytoplasmic droplet, modification of the acrosome, sperm motility and increased chromatin packaging. All these processes finally allow the maturation of the sperm cells, which capacitates them for fertilization. Thus, any factor that affects sperm production in the testis or in the epididymis will necessarily affect the number and shape of sperm cells (Okamura et al., 2009). 
Choudhary et al. (2008) describe that organophosphates in rats induce significant effects on some testis variables such as decreased testicular weight, associated with a lower sperm density in the epididymis and a fall in rates of fertilization.

\section{RESULTS}

The Figure 1 shows normal, species-specific morphology of spermatozoids of various biocentinel species, including the human species. The Figure 2 shows immunohistochemical tests by BrdU technique in spermathecae of control worms and treated with malathion. Controls (a: 10x, c: 100x), with spermatozoa ordered and included in the microvellocities (green arrow). Treated worms (b and d), show an epithelial unit with large vacuolations (arrowhead) and spermatozoa accumulation in the center of the spermatheca (black arrow), not incorporated to the miicrovilli (green arrow).

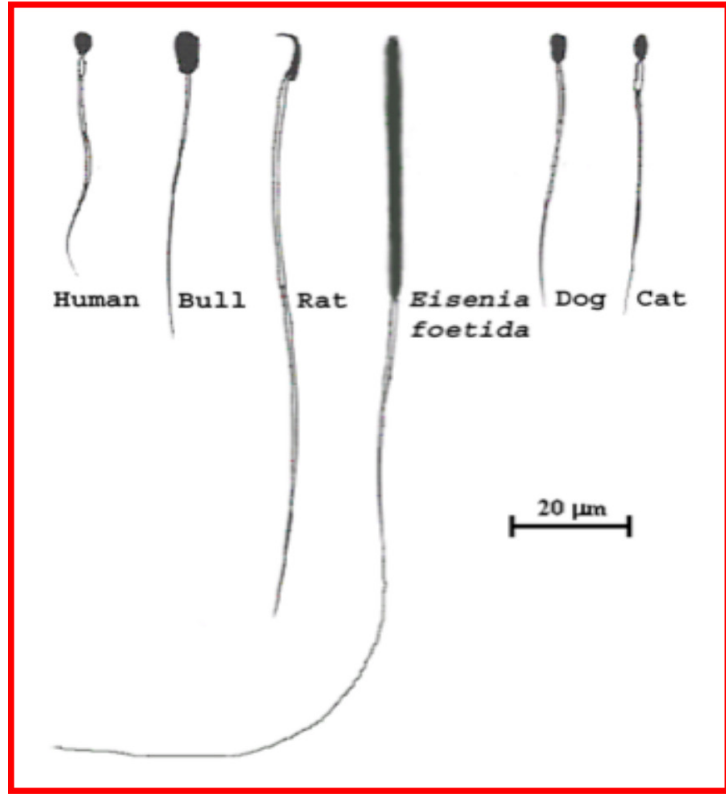

Fig. 1. Species-specific morphology of spermatozoids of various biosentinel species, including the human species.
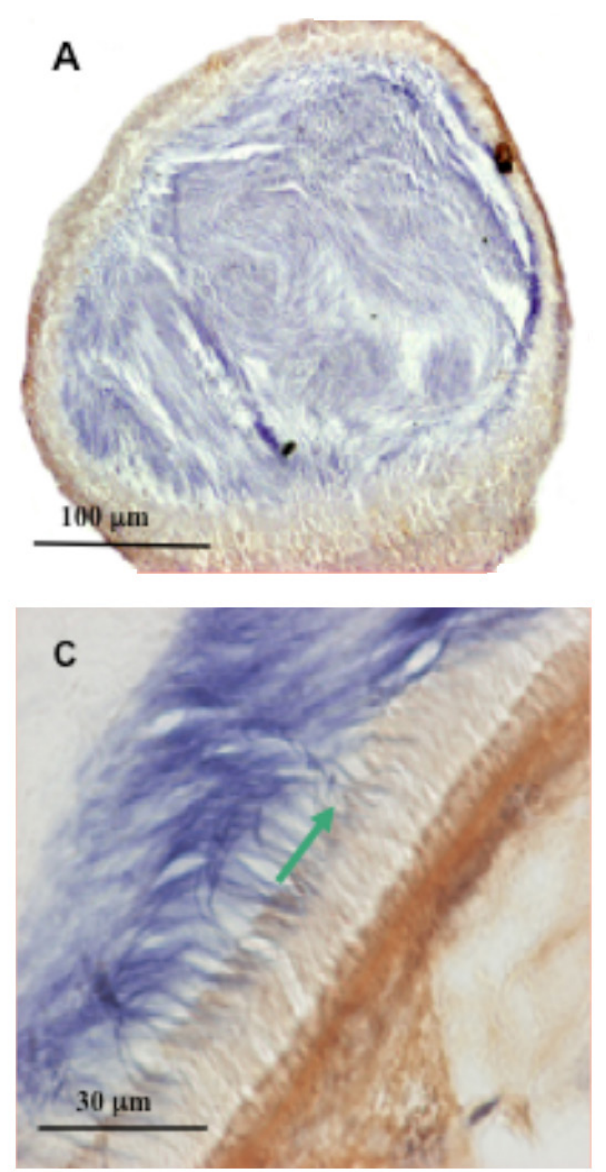

Fig. 2. Spermathecae of control worms (a:10X; c:100X) and treated worms with malathion (b: 10x, d: 100x). Immuno-histochemical tests by BrdU technique. 
The Figure 3 shows a microphotography of seminiferous tubules (40x) of mouse group treated with malathion, 43 days post treatment where tubular plugging $(\mathrm{T})$ and vacuolization of the germinal epithelium (V) are observed.

The Table I shows the lethal dose 50 (LD50), for each of the organophosphates (malathion, diazinon and methamidophos) in biosentinel species and in the human species.

The analysis of our results show that in rats and mice, malathion damages the testis, epididymis and germinal epithelium, with decreased sperm count and increased teratozoospermia, which result in plugging of the seminiferous tubules caused by the weakening of adluminal cell unions between testicular sustentocyte cells -the blood-testis barrier-, which implies premature release of meiotic cells during spermiohistogenesis. The increase in the rates of teratozoospermia is mostly related to abnormalities of the sperm tail and in a lesser extent to sperm head anomalies. Ultrastructural alterations on sustentocyte cells have also been reported, which causes vacuolation. The alkylating properties of OPs might be reflected in the interference with the normal assembly of sperm flagellar proteins (Espinoza-Navarro et al., 2015).

The results observed on Eisenia foetida exposed to malathion, diazinon and methamidophos show that these compounds alter the external morphology in earthworms with a significant decrease in body weight and provoking muscle contraction manifested by coiled tails. In the reproductive tract, OPs alter the spermatheca and the morula stage with an initial significant increase of immature sperm followed by a significant decrease of sperm count. Other studies in sperm assessed by the Acridine Orange Test show a significant increase of metachromatic cells with altered DNA (Espinoza-Navarro \& Bustos-Obregón, 2005).

These results are conclusive in determining the toxicity of these organophosphorus insecticides in the male reproductive system, thus subsequently altering the fertility of the exposed species. This toxic effect exerts a synergistic action in organic systems which varies depending on different chemical mixtures the individual is exposed to.
Studies related to the exposure to pesticides in agriculture and other occupational and domestic uses are needed in order to implement best policies on management, biosafety and biocontainment of these contaminants, so they do not alter the environment and human public health.

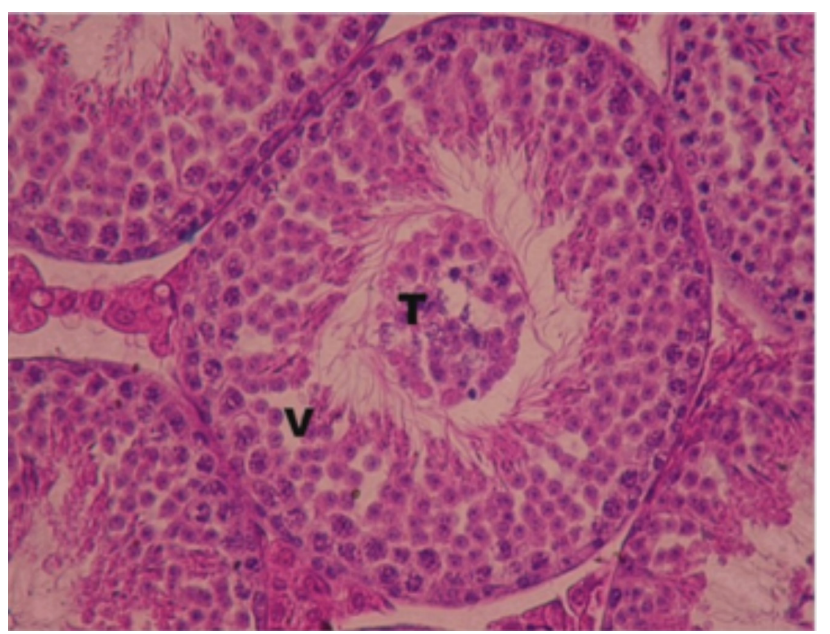

Fig. 3. Microphotography of seminiferous tubules (40x) of mouse group treated with malathion, tubular plugging $(\mathrm{T})$ and vacuolization of the germinal epithelium (V).

\section{DISCUSSION}

The effect of pesticides on the environment and global public health is an issue that demands greater care in the management of these products in order to avoid collateral damages. The World Health Organization (2005), proposes a taxonomy of the level of toxicity of pesticides classifying them by color and level, where a red label with levels Ia and Ib are considered extremely dangerous and very dangerous respectively, the majority of organophosphorus insecticides are incorporated in this group. In Chile, the agricultural sector holds $13 \%$ of the workforce and provides about 772,000 permanent jobs, to which a significant number of temporary jobs (temporary workers, who are workers with low occupational and health care) are added during continually increasing periods of time. This has allowed a substantial raise in the sales and application

Table I. The lethal dose 50 (LD50), for each of the organophosphates (malathion, diazinon and methamidophos) in biosentinel species and in the human species.

\begin{tabular}{lllll}
\hline & Human & Rat & Mice & E. Foetida \\
\hline Malathion & $24 \mathrm{mg} / \mathrm{kg}$ weight & $680 \mathrm{mg} / \mathrm{kg}$ weight & $2400 \mathrm{mg} / \mathrm{kg}$ weight & $880 \mathrm{mg} / \mathrm{kg}$ soil \\
Diazinon & $0,02 \mathrm{~g} / \mathrm{kg}$ weight & $1600 \mathrm{mg} / \mathrm{kg}$ weight & $65 \mathrm{mg} / \mathrm{kg}$ weight & $63 \mathrm{mg} / \mathrm{kg}$ soil \\
Methamidophos & $0,2 \mathrm{mg} / \mathrm{kg}$ weight & $85,4 \mathrm{mg} / \mathrm{kg}$ weight & $100 \mathrm{mg} / \mathrm{kg}$ weight & $90 \mathrm{mg} / \mathrm{kg}$ soil. \\
\hline
\end{tabular}


of pesticides. Natural resources such as water, soil and air have already been affected by these pesticides, which in order of use correspond in $21 \%$ to organophosphates, 11.8 $\%$ to carbamates and $4.8 \%$ to triazicides (pyrethroids). In Arica, Chile, one of the most commonly used pesticides is malathion, which was widely used in the agricultural valleys of Lluta and Azapa to eradicate the fruit fly Ceratitis capitata; however, other species were also affected, thus altering the balance of the environment (Muñoz-Quezada, 2001; WHO, 2006; MINSAL, 2014).

Occupational exposure to organophosphate in agriculture-related workers and in the general population can occur via dermal, respiratory and oral pathways, especially in cases of accidents or improper handling. These pesticides are second in the percentage of cases with severe occupational poisoning, with signs or symptoms related to possible mortality. Acute poisoning results in neurological and psychiatric damage in a process still unclear (Eddleston et al., 2008).

The World Health Organization (2008), reports that each year the use of insecticides causes approximately one million accidental poisonings and two million deliberate poisonings (suicides) worldwide, with 200,000 of these resulting in death, a number which has become a major public health problem that is urgent to be controlled. Mortality from organophosphates use is high -with a rate of $10 \%$ - in comparison to mortality from the use of other chemicals, with an incidence of $0.5 \%$. The Environmental Protection Agency (EPA) and scientific experts warn about the correct use of this type of pesticide (Thundiyil, et al., 2008; Hossain et al., 2010; Damalas \& Eleftherohorinos, 2011; Egeghy et al., 2011).

Evaluations performed in agricultural areas of Chile, with a $34 \%$ rural population, have determined that $17.8 \%$ of students enrolled in primary education present intellectual disability, the highest percentage in Chile. In women with temporary agriculture-related jobs, the use of pesticides has been associated with spontaneous abortions, births of children with malformations, impaired reproductive health and cytogenetic damage. The main sources of poisoning might be the water and vegetables in the diet of this population. These results coincide with the findings of authors in other world populations with high rates reported in the use of these compounds (Muñoz-Quezada, 2010; Ríos \& Solari, 2010; Muñoz-Quezada et al., 2016).

As noted, exposure to these pesticides is observed not only in the workplace as a direct result of occupational handling, but also indirectly through domestic consumption of polluted water or food. School child population deserves more attention in this aspect, given its higher vulnerability, reduced detoxificating capacity, endocrine and physiological effects overall (Muñoz-Quezada, et al., 2014).

Current studies on remediation and monitoring include the use of numerous poisoning markers, using technology to detect the residues of these contaminants in blood, urine and breast milk. The use of antioxidants as protective agents from pollution has also been reported. Globally, it is essential to implement toxicological and environmental laboratories for exhaustive and reliable pesticide biomonitoring, in order to develop better policies on the management, biosafety and biocontainment of these pollutants. It is important to generate greater bioethics concern in governmental authorities as well as in the population that continues marketing and indiscriminately applying these high toxicity pesticides and their residues, using them in popular vegetable products with high sales or consumption rates, thus altering the environment and public health (Kavvalakis \& Tsatsakis, 2012).

\section{CONCLUSIONS}

Our studies show the toxicity of organophosphorus insecticides, malathion, diazinon and methamidophos, on male reproduction. The bad management of these chemical compounds expresses a synergistic effect the whole organism, with acute effects like poisoning and death and chronic effects like congenital malformations, reproductive immune disorders, and cancer. International and regional organizations alert on the correct use of these synthetic chemicals in the workplace, in the use of water, food and at home, focusing greater attention on agricultural and child population.

ACKNOWLEDGMENTS. This research was supported by Universidad de Tarapacá via UTA Major Project: No 4716-17.

ESPINOZA-NAVARRO, O.; PONCE-LAROSA, C. \& BUSTOS-OBREGÓN, E. Pesticidas organofosforados: sus efectos en especies biosentinelas y humanos. Control y aplicación en Chile. Int. J. Morphol., 35(3):1069-1074, 2017.

RESUMEN: El medio ambiente se ve afectado negativamente por la creciente acumulación de desechos y subproductos naturales y artificiales. Los plaguicidas organofosforados malatión, diazinón y metamidofos, son usados en todo el mundo en el control de plagas. El objetivo de este trabajo fue revisar los efectos de los organofosforados en el tracto reproductivo masculino de ratones, ratas y lombrices de tierra, y evaluar su proyección en la población humana. La evaluación de fallas en el sistema reproductor masculino es un 
excelente biomarcador in vivo para determinar el nivel de toxicidad de los contaminantes químicos. En roedores, los organofosforados causan disminución del peso testicular y de la densidad espermática, obstrucción tubular anormal y aumento de la teratozoospermia. En lombrices de tierra causan una disminución significativa en el peso corporal y alteran la espermateca, con un aumento inicial significativo en espermatozoides inmaduros, seguido de una disminución significativa en el recuento de espermatozoides con alta frecuencia de metacromasia. Dado el impacto medioambiental de estos plaguicidas y sus efectos potenciales en la salud humana, las organizaciones internacionales y regionales advierten sobre el manejo y uso correctos de estas sustancias durante exposiciones laborales y domésticas y sobre su relación con la contaminación de las fuentes de agua y alimentos, colocando énfasis en la población de niños en edad escolar, debido a su mayor vulnerabilidad, reducción de la capacidad de desintoxicación y sus efectos a nivel endocrino y fisiológico.

PALABRAS CLAVE: Organofosforados; Citotoxicidad; Biomonitorización; Salud Reproductiva; Exposición Ocupacional.

\section{REFERENCES}

Agency for Toxic Substances and Disease Registry (ATSDR). Registro Técnico para Profesionales de la Salud Pública. Atlanta, Agency for Toxic Substances and Disease Registry, 2000.

Baconi, D. L.; Bârca, M.; Manda, G.; Ciobanu, A. M. \& Balalau, C. Investigation of the toxicity of some organophosphorus pesticides in a repeated dose study in rats. Rom. J. Morphol.Embryol., 54(2):349-56, 2013.

Bello-Ramírez, A. M.; Carreón-Garabito, B. Y. \& Nava-Ocampo, A. A. A theoretical approach to the mechanism of biological oxidation of organophosphorus pesticides. Toxicology, 149(2-3):63-8, 2000.

B?asiak, J.; Ja?oszynski, P.; Trzeciak, A. \& Szyfter, K. In vitro studies on the genotoxicity of the organophosphorus insecticide malathion and its two analogues. Mutat. Res., 445(2):275-83, 1999.

Bustos-Obregón, E. \& Hartley, B. R. Ecotoxicology and testicular damage (environmental chemical pollution): A review. Int.J.Morphol.26(4):83340, 2008.

Choudhary, N.; Goyal, R. \& Joshi, S. C. Effect of malathion on reproductive system of male rats. J. Environ. Biol., 29(2):259-62, 2008.

Damalas, C. A. \& Eleftherohorinos, I. G. Pesticide exposure, safety issues, and risk assessment indicators. Int. J. Environ. Res. Public Health, 8(5):1402-19, 2011

Eddleston, M.; Buckley, N. A.; Eyer, P. \& Dawson, A. H. Management of acute organophosphorus pesticide poisoning. Lancet, 371(9612):597-607, 2008.

Egeghy, P. P.; Cohen Hubal, E. A.; Tulve, N. S.; Melnyk, L. J.; Morgan, M. K.; Fortmann, R. C. \& Sheldon, L. S. Review of pesticide urinary biomarker measurements from selected US EPA children's observational exposure studies. Int. J. Environ. Res. Public Health, 8(5):1727-54, 2011.

Environmental Protection Agency (EPA). Pesticide News story: The EPA publishes amended Azinphos-Methyl cancellation order allowing use of existing stocks through September 2013. Environmental Protection Agency, 2012. Available from: www.epa.gov/pesticides/chemicalsearch/

Espinoza-Navarro, O. \& Bustos-Obregón, E. Effect of malathion on the male reproductive organs of earthworms, Eisenia foetida. Asian J. Androl., 7(1):97-101, 2005

Espinoza-Navarro, O. \& Bustos-Obregón, E. Effects of malathion on cellularity and sperm differentiation in testis and epididymis of adult rats. Int J. Morphol., 32(1):119-24, 2014

Espinoza-Navarro, O.; Rodríguez, B. H.; Kemble, M. H. \& Arriaza, O. C.
Efecto del insecticida malathion sobre el epitelio germinativo de testículo de ratón CF1. Interciencia, 40(8):560-3, 2015.

García-Santos, G. \& Keller-Forrer, K. Avoidance behaviour of Eisenia fetida to carbofuran, chlorpyrifos, mancozeb and metamidophos in natural soils from the highlands of Colombia. Chemosphere, 84(5):651-6, 2011.

Hossain, F.; Ali, O.; D’Souza, U. J. \& Naing, D. K. Effects of pesticide use on semen quality among farmers in rural areas of Sabah, Malaysia. J. Occup. Health, 52(6):353-60, 2010.

Joshi, S. C. \& Sharma, P. Male reproductive toxicity of organophosphorous compounds: A review. Toxicol. Environ. Chem., 93(7):1486-507, 2011.

Kavvalakis, M. P. \& Tsatsakis, A. M. The atlas of dialkylphosphates; assessment of cumulative human organophosphorus pesticides' exposure. Forensic Sci. Int., 218(1-3):111-22, 2012.

Ministerio de Salud (MINSAL). Decreto $N^{o} 158$. Reglamento sobre condiciones para la seguridad sanitaria de las personas en la aplicación terrestre de plaguicidas. Santiago de Chile, Ministerio de Salud, Gobierno de Chile, 2014.

Muñoz-Quezada, M. T. Uso de plaguicidas y discapacidad intelectual en estudiantes de escuelas municipales, Provincia de Talca, Chile. Rev.Fac. Nac. Salud Pública, 28(1):29-35, 2010.

Muñoz-Quezada, M. T.; Lucero, B.; Iglesias, V. \& Muñoz, M. P. Vías de exposición a plaguicidas en escolares de la Provincia de Talca, Chile. Gac. Sanit., 28(3):190-5, 2014.

Muñoz-Quezada, M. T.; Lucero, B.; Iglesias, V.; Muñoz, M. P.; Achú, E.; Cornejo, C.; Concha, C.; Grillo, A. \& Brito, A. M. Plaguicidas organofosforados y efecto neuropsicológico y motor en la Región del Maule, Chile. Gac. Sanit., 30(3):227-31, 2016.

Muñoz-Quezada, Q. M. T. Aspectos bioéticos en el control y aplicación de plaguicidas en Chile. Acta Bioethica, 17(1):95-104, 2001.

Okamura, A.; Kamijima, M.; Ohtani, K.; Yamanoshita, O.; Nakamura, D.; Ito, Y.; Miyata, M.; Ueyama, J.; Suzuki, T.; Imai, R.; Takagi, K. \& Nakajima, T. Broken sperm, cytoplasmic droplets and reduced sperm motility are principal markers of decreased sperm quality due to organophosphorus pesticides in rats. J. Occup. Health, 51(6):478-87, 2009.

Phugare, S.; Gaikwad, Y. \& Jadhav, J. P. Biodegradation of acephate using developed bacterial consortium and further toxicological analysis using earthworm (Lumbricus terrestris) as a model animal. Int. Biodeterior. Biodegrad., 69:1-9, 2012.

Ríos, B. J. C. \& Solari, G. S. Biomonitorización de plaguicidas: ¿Una necesidad del país?. Rev. Med. Chile, 138(4):515-8, 2010.

Rodríguez, H. \& Bustos-Obregón, E. An in vitro model to evaluate the effect of an organophosphoric agropesticide on cell proliferation in mouse seminiferous tubules. Andrologia, 32(1):1-5, 2000.

Salazar-Arredondo, E.; de Jesús Solís-Heredia, M.; Rojas-García, E.; Hernández-Ochoa, I. \& Quintanilla-Vega, B. Sperm chromatin alteration and DNA damage by methyl-parathion, chlorpyrifos and diazinon and their oxon metabolites in human spermatozoa. Reprod.Toxicol., 25(4):455-60, 2008.

Thundiyil, J. G.; Stober, J.; Besbelli, N. \& Pronczuk, J. Acute pesticide poisoning: a proposed classification tool. Bull. World Health Organ., 86(3):205-9, 2008

World Health Organization (WHO). Classification and Guideline of Pesticides by Hazard. Geneva, World Health Organization, 2006.

Yasmin, S. \& D'Souza, D. Effects of Pesticides on the Growth and Reproduction of Earthworm: A Review. App. Environ. Soil Sci., 2010:678360, 2010.

\section{Corresponding Author: \\ Dr. Omar Espinoza Navarro \\ Universidad de Tarapaca \\ Arica \\ CHILE}

Received: 02-05-2017

E-mail: oespinoz@uta.cl
Accepted: 12-06-2017 